University of Nebraska - Lincoln

DigitalCommons@University of Nebraska - Lincoln

Investigations of the Ichthyofauna of

Nicaraguan Lakes

Papers in the Biological Sciences

1976

Rectal Glands of Marine and Fresh-Water Sharks: Comparative

Histology

Mikio Oguri

Nagoya University

Follow this and additional works at: https://digitalcommons.unl.edu/ichthynicar

Part of the Aquaculture and Fisheries Commons

Oguri, Mikio, "Rectal Glands of Marine and Fresh-Water Sharks: Comparative Histology" (1976).

Investigations of the Ichthyofauna of Nicaraguan Lakes. 48.

https://digitalcommons.unl.edu/ichthynicar/48

This Article is brought to you for free and open access by the Papers in the Biological Sciences at DigitalCommons@University of Nebraska - Lincoln. It has been accepted for inclusion in Investigations of the Ichthyofauna of Nicaraguan Lakes by an authorized administrator of DigitalCommons@University of Nebraska Lincoln. 
Copyright by the American Association for the Advancement of Science

\section{Rectal Glands of Marine and Fresh-Water Sharks: Comparative Histology}

Abstract. The rectal glands of elasmobranchs perform the function of saltexcreting organs. These glands are smaller and show regressive changes in specimens of the bull shark, Carcharhinus leucas found in fresh-water environment, compared with specimens of this and other species from a marine habitat.

The physiological significance of the rectal gland was obscure for a long time, though some morphological investigations were made $(I)$. Recently the excretion of sodium chloride was reported as the main function of the gland (2). Elasmobranchs are marine fish, but a few adapt to the fresh-water environment (3). The bull shark, Carcharhinus leucas (Müller and Henle), is common in the Gulf of Mexico and Atlantic Ocean, but it also lives in Lake

Nicaragua (4) and some fresh-water situations in the United States (5). This report deals with morphological cifferences in the rectal glands of marine and fresh-water $C$. leucas.

The rectal glands investigated were from six marine and ten fresh-water specimens of $C$. leucas. Also, for reference, the rectal glands were investigated in the following additional species of marine sharks: blacktip shark, $C$. limbatus (two specimens), tiger shark,

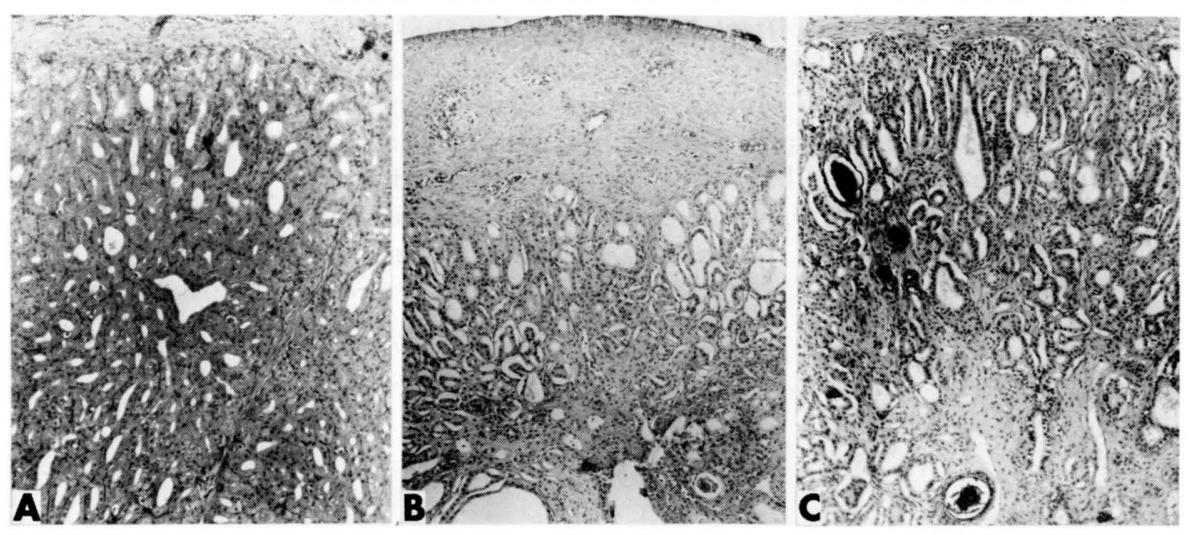

Fig. 1. Rectal glands of bull sharks, Carcharhinus leucas (hematoxylin and eosin; $X$ 114). $A$, Marine shark, female (No. 11 in Table 1 ); $B$, fresh-water shark, male (No. 2 in Table 1); $C$, fresh-water shark, female (No. 3 in Table 1). e 1. Rectal glands of fresh-water and marıne sharks. The fresh-water species were collected at Lake Nicaragua and Rio. San Juan in June and July 1963, the marine species at Cape Haze, July to November 1963.

\begin{tabular}{|c|c|c|c|}
\hline \multirow{2}{*}{$\begin{array}{c}\text { Ani- } \\
\text { mal } \\
\text { No. }\end{array}$} & \multirow[b]{2}{*}{ Sex } & \multirow{2}{*}{$\begin{array}{l}\text { Body } \\
\text { length } \\
(\mathrm{cm})\end{array}$} & Rectal gland \\
\hline & & & $\begin{array}{l}\text { Length Weight } \\
(\mathrm{cm}) \quad(\mathrm{g})\end{array}$ \\
\hline
\end{tabular}

\begin{tabular}{|c|c|c|c|c|}
\hline \multicolumn{5}{|c|}{ Fresh water: $C$. leucas } \\
\hline 1 & $\mathrm{~F}^{*}$ & 170 & 4.5 & 1.1 \\
\hline 2 & $M^{*}$ & 158.4 & 6.5 & 0.6 \\
\hline 3 & $\mathrm{~F}^{\dagger}$ & 188.2 & 6.5 & 1.5 \\
\hline 4 & $\mathrm{M}^{\dagger}$ & 174 & 6.7 & 0.6 \\
\hline 5 & $\mathrm{~F} \ddagger$ & 155 & 6.0 & 0.8 \\
\hline 6 & $\mathrm{M} \ddagger$ & 147.5 & 6.4 & 0.7 \\
\hline 7 & $\mathrm{~F} \S$ & $(127.2)$ & 6.0 & 0.35 \\
\hline 8 & $\mathrm{~F} \S$ & 135 & 3.8 & 0.35 \\
\hline 9 & $\mathrm{~F} \S$ & 157 & 4.0 & 0.4 \\
\hline 10 & $\mathrm{~F} \S$ & $(165.6)$ & 4.2 & 0.45 \\
\hline \multicolumn{5}{|c|}{ Marine: C. leucas } \\
\hline 11 & $\mathbf{F}$ & 215.5 & & \\
\hline 12 & $\mathrm{~F}$ & 231.0 & & \\
\hline 13 & $F$ & 246.0 & 8.2 & 6.5 \\
\hline 14 & $\mathrm{~F}$ & 261.2 & 9.8 & 15.9 \\
\hline 15 & M & 185.9 & 7.4 & 3.8 \\
\hline 16 & $F$ & 200.7 & 9.1 & 7.6 \\
\hline \multicolumn{5}{|c|}{ Marine: $C$. limbatus } \\
\hline 17 & M & 142.5 & 3.2 & 1.5 \\
\hline 18 & $\mathrm{~F}$ & 161.3 & 5.4 & 3.0 \\
\hline & Mar & Galeocer & cuvieri & \\
\hline 19 & $F$ & 196.4 & 8.5 & 6.1 \\
\hline 20 & M & 212.7 & 10.8 & 8.2 \\
\hline 21 & $\begin{array}{c}\text { Marin } \\
\mathbf{M}\end{array}$ & $\begin{array}{c}\text { Negaprion } \\
265\end{array}$ & $\begin{array}{c}\text { evirostr } \\
7.3\end{array}$ & 12.0 \\
\hline
\end{tabular}

* Collected at El Castillo. † Collected at San Carlos. $¥$ Collected at San Juan del Norte. Colfected at Los Coco

Galeocerdo cuvieri (two specimens), and lemon shark, Negaprion brevirostris (one specimen). Four rectal glands of marine sharks (Nos. 11, 12, 14, and 17 in Table 1) were fixed in Zenker-formol for histological examination. The rectal glands of fresh-water sharks were originally preserved in 70 percent ethyl alcohol, but they were fixed with Zenker-formol for routine histological procedures $(6,7)$.

Table 1 shows the measurements and other data on the rectal glands of bull sharks used in this study. For reference the data concerning three other species of marine sharks were included. A remarkable difference was observed in the size of rectal glands from marine bull sharks compared to those from Lake Nicaragua and Rio San Juan, even if the smaller size of the fresh-water sharks is taken into consideration. The weight of the rectal gland was greatly reduced, especially in four females from Los Cocos near Granada. In the histological preparations differences were also detected. The rectal glands of marine sharks are compound tubular glands, as shown in Fig. $1 \mathrm{~A}$ which is a section from a female bull shark (No. 
11 in Table 1). The cytoplasm of the excretory cells is granular, and it stained in the form of basal filament with eosin or phloxine. Cytological, histochemical, and electron microscope observations were made on the rectal glands of marine elasmobranchs by Bernard and Hartmann (8) and Doyle (9), and high activity in tubular cells was demonstrated morphologically.

The rectal glands from fresh-water sharks showed regressive changes. Figure 1 ( $B$ and $C$ ) shows the rectal glands of male and female sharks caught at El Castillo and San Carios, respectively (Nos. 2 and 3 in Table 1 ). The glandular tubules are decreased in number, and the interstitial tissue between these tubules is increased in proportion. Some tubules are shrunken, and others are swollen. Laminated bodies resembling the casts and corpora amylacea found in renal tubules and prostatic ducts of man (10) are observed often within the lumina of these tubules (Fig. 1C). These bodies stain with PAS, iron-hematoxylin, phloxine, or chrome-hematoxylin, and are associated with tubular dilation and epithelial compression.

Thus, it seems that the rectal glands of Lake Nicaragua sharks become hypofunctional, or quiescent, and finally regressive changes associated with living in a fresh-water environment occur in their structure. These observations support the theory of Burger and Hess that the main function of the rectal gland is to excrete sodium chloride. It is not definitely known whether Lake Nicaragua sharks remain in the lake throughout life or whether they migrate back and forth between fresh water and the Caribbean Sea. The regressive changes were detected also in the rectal glands of sharks caught at the San Juan del Norte (Greytown), at the mouth of the Rio San Juan (Nos. 5 and 6 in Table 1). This suggests that they migrate (up and down) between Lake Nicaragua and the sea.

Cape Haze Marine Laboratory,

Sarasota, Florida

\section{References and Notes}

1. D. R. Crofts, Proc. Zool. Soc. (London) 101 (1925)

2. J. W. Burger and W. N. Hess, Science 131, 670 (1960); J. W. Burger, Physiol. Zool. 35 205 (1962).

11, 49 (1936)

4. Lake Nicaragua shark (Carcharhinus nicaraguensis) is said to be the same species as the bull shark. C. leucas [H. B. Bigelow and W. C. Schroeder. Coneia 1961, 359 (1961)].

5. P. Francis, Florida Wildlife, 14, 12, 36 (Apr. 1961); R. M. Darnell, Inst. Marine Sct. 5, 353 (1958).

6. I thank Thomas B. Thorson, Department of Zoology and Physiology, University of $\mathrm{Ne}$ braska, for supplying the rectal glands of Lake Nicaragua sharks and also for his comments.

7. The histological stains used are as follows: Ehrlich's acid hematoxylin and eosin; Gomori's chrome-hematoxylin and phloxine; Heidenhain's iron-hematoxylin and fast green and periodic acid-Schiff (PAS) reaction.

8. G. R. Bernard and J. F. Hartmann, Anat. Rec. 137, 340 (1960).

W. L. Doyle, ibid. 142, 228 (1962); Am. J. Anat. 111, 223 (1962)

10. A. C. Allen, The Kidney, Medical and Surgical Disease (Grune \& Stratton, New York, 1962); P. A. Herbut, Urological Pathology (Lea \& Febiger, Philadelphia, 1952)

11. This study was supported by ONR grant (Nonr G-00016-63). I thank Eugenie Clark, director of the Cape Haze Marine Laboratory, for her encouragement and valuable comments in this study. I thank J. S. Bracken for supplying the facilities of Selby Memorial Laboratory of the Sarasota County Memorial Hospital, and for his valuable advice.

* Present address: National Institute of Radiological Sciences, 250, Kurosuna, Chiba, Japan.

6 January 1964 